\title{
Effects of Housing, Management, and Health of Dairy Heifers on First-Lactation Udder Health in Southwest Sweden
}

\author{
C. Svensson, ${ }^{\star 1}$ A.-K. Nyman, †§ K. Persson Waller,†‡ and U. Emanuelson† \\ *Department of Animal Environment and Health, Swedish University of Agricultural Sciences, Skara, Sweden \\ †Department of Clinical Sciences, Swedish University of Agricultural Sciences, Uppsala, Sweden \\ ‡Department of Pigs, Poultry and Ruminants, National Veterinary Institute, Uppsala, Sweden \\ §wedish Dairy Association, Eskilstuna, Sweden
}

\begin{abstract}
Data on health, management, and housing from birth to first calving were collected for 2,126 heifers on semimonthly visits made by project veterinarians to 107 dairy herds from southwest Sweden. Additional data were obtained from the official milk- and health-recording program. Factors associated with incidence of veterinarian-treated clinical mastitis (VTCM) in the period $7 \mathrm{~d}$ before $(\mathrm{d}-7)$ to $30 \mathrm{~d}$ after first calving and of elevated cow composite somatic cell count (SCC, $\geq 200,000$ cells $/ \mathrm{mL}$ ) at first test milking after first calving, respectively, were investigated using a 2-level (animal and herd) logistic regression analysis after initial screening by univariate analyses. The incidence risk of VTCM during the complete first lactation (305 d) was $10.8 \%$. Ten percent of the diseased animals had more than 1 case of VTCM and $51 \%$ of total cases occurred from -7 to $30 \mathrm{~d}$ postcalving. The incidence rate of VTCM during the complete first 305-d lactation was 1.13 cases per 100 cow-mo. In total, $18.1 \%$ of the animals had elevated SCC at first test milking (mean $21 \mathrm{~d}$ ) after calving. Veterinarian-treated clinical mastitis at -7 to $30 \mathrm{~d}$ postcalving was associated with higher overall incidence of mastitis in the herd and with reproductive disorders (i.e., retained placenta, endometritis, pyometra, dystocia, or twin birth). The risk of elevated SCC increased with increasing percentage of cows in the herd that, some time during the year, had had an increased udder disease score (chronically increased SCC). Other factors associated with increased risk of elevated SCC were increasing amounts of concentrates fed to 11- to 16-mo-old heifers, moving to confined housing the day of calving instead of earlier, and use of restraint measures at milking. In addition, growth rate from birth to weaning, and several feed-related variables (e.g., amount of concentrates and type of roughage given) were associated with VTCM at -7 to $30 \mathrm{~d}$ post-
\end{abstract}

Received July 5, 2005.

Accepted December 21, 2005.

${ }^{1}$ Corresponding author: Catarina.Svensson@hmh.slu.se calving or elevated SCC at first test milking in the univariate analyses.

Key words: calf, replacement heifer, mastitis, somatic cell count

\section{INTRODUCTION}

Clinical and subclinical mastitis constitutes the most costly disease in modern dairy production (e.g., DeGraves and Fetrow, 1993; Seegers et al., 2003). In Nordic countries, the incidence of clinical cases of mastitis (CM) has been reported to range from 15.9 to $28.1 \%$ (Valde et al., 2004). In Sweden, the total morbidity in dairy cows was 32.7 cases per 100 lactations during 2003-2004, of which CM accounted for half of the cases (Swedish Dairy Association, 2005). Mastitis therapy accounts for the largest proportion of antibiotic drug use in dairy production and mastitis therapy has therefore become a prime target in the effort to control development of antibiotic resistance in microorganisms by decreasing antibiotic drug use. However, in Sweden, only veterinarians are allowed to start an antibiotic treatment, and every treatment should be reported to the national animal disease recording system. To minimize the use of antibiotics, considerable research has been conducted to identify effective prophylactic measures to control mastitis. So far, this has almost exclusively focused on the adult dairy cow. Udder infections have, however, been documented in heifers prepartum (Oliver and Mitchell, 1983; Trinidad et al., 1990; Edinger et al., 1999) and several studies report a high prevalence of CM during the first lactation (Pankey et al., 1991; Barkema et al., 1998; Valde et al., 2004). Valde et al. (2004) also documented that during the first month of lactation, first-lactation heifers had a higher incidence of CM than did second-parity cows, and nearly as high as third-parity cows. When Swedish dairy herds with low bulk milk SCC and high milk production were studied, a considerable proportion of the cases of veterinarian-treated clinical mastitis (VTCM) were attributed to first-lactation heifers (Emanuelson and Hallén Sandgren, 1997). Similarly, heifer mastitis was a common 
disease also in well-managed, high-yielding Finnish herds with low SCC and a high frequency of veterinary mastitis treatments (Myllys and Rautala, 1995). Mastitis before parturition and within the first week postpartum increase risks of mastitis later in lactation and of culling in primiparous cows (Edinger et al., 1999; Waage et al., 2000). Both clinical and subclinical mastitis have a negative effect on milk production (Hortet et al., 1999; Rajala-Schultz et al., 1999). Therefore, studies that focus on risk factors for impaired udder health of first-lactation heifers are warranted.

Most cases of CM in primiparous cows (as in older cows) occur early in lactation (Myllys and Rautala, 1995; Barkema et al., 1998; Valde et al., 2004), stressing the importance of the immune functions during the periparturient period, but also indicating a possible role of rearing factors. However, few studies have investigated the effects of housing, feeding, and management of calves and replacement heifers on their subsequent udder health. Myllys and Rautala (1995) associated feeding homemade concentrates (cereal grains) with an increased risk of $\mathrm{CM}$ in primiparous cows, and Østerås et al. (1997) reported group housing between 2 mo of age and breeding, and milk feeding to preweaned calves by other means than bucket or artificial teat, to be risk factors for CM. Barkema et al. (1999) and Bareille et al. (2004) found an increased risk of CM in herds housing heifers together with older cows. Bareille et al. (2000) reported that transition diets that included concentrates with a high protein content, introduction of heifers to the lactating cow herd before calving, and presence of older cows with elevated SCC were all associated with an increased prevalence of elevated SCC in heifers.

The aims of the present study were to describe the incidence of mastitis and to explore the associations of housing, management, and health of calves and replacement heifers, with clinical and subclinical mastitis in early lactation of primiparous cows. Data were from a long-term study on the health of calves and replacement heifers in Swedish dairy herds.

\section{MATERIALS AND METHODS}

We enrolled 122 dairy farms (herd size: 28 to 94 cows; Table 1) in the county of Skaraborg in the southwest of Sweden. The farms had been selected on basis of their housing system for calves and replacement heifers, as described by Lundborg et al. (2003). In 1998, herd sizes in the range of 28 to 94 cows represented $56 \%$ of all Swedish dairy herds. In the selected farms, all heifer calves born in 1998 were monitored by research staff from birth to first calving (or from birth to the day of their removal from the study). Of 3,081 animals included, 179 (5.8\%) died, 267 (8.7\%) were slaughtered,
$259(8.4 \%)$ were sold before calving, and 250 (8.1\%) were lost because the farmer could no longer participate or because their membership status in the official milkand health-recording program changed. The remaining 2,126 animals from 107 herds were included in the present study. Calves were kept in single pens, or in group pens bedded with straw or sawdust until weaning, and then in group pens with slatted floors or in litter pens (i.e., in group pens bedded with straw and bedding removed at intervals $>3 \mathrm{mo}$ ). The distribution of housing systems for heifers 2 mo before calving is shown in Table 3.

\section{Data Collection}

The farmers were requested to measure the heart girth of the animals at birth, weaning, first insemination, and calving. The heart girth was transformed to live weight and daily weight gains were calculated individually for the periods from birth to weaning, and from first insemination to calving (for details, see Hessle et al., 2004).

Diseases prepartum were recorded by farmers and by project veterinary surgeons visiting the farms semimonthly to make a brief physical examination of the calves. The project veterinarians also recorded the housing system used for each animal and interviewed the farmers about grazing and claw trimming routines, practices to adapt heifers to milking and use of restraint measures. They collected information about the indoor feed rations offered and weighed the amounts of feed ingredients given daily to calves and heifers within specific age groups (for details, see Hessle et al., 2004).

Information on monthly milk production, monthly cow composite SCC, and on diseases for each individual from first calving until $305 \mathrm{~d}$ of lactation or culling was obtained from the official milk- and health-recording program. This program includes $86 \%$ of all dairy herds in Sweden (Swedish Dairy Association, 2005) and is based on disease reports from veterinarians treating the cases and on results (e.g., those from test milkings) reported monthly by farmers. For a closer description of the program, see Andersson (1988) and Olsson et al. (2001). All reported cases of clinical mastitis were diagnosed by trained veterinary practitioners. The diagnosis was based on the presence of local inflammatory signs characterizing clinical mastitis, such as udder swelling and presence of abnormal milk. At each monthly test milking, an udder disease score (UDS) was calculated for each cow from the herds affiliated with the recording program. The UDS is a measurement of the udder health of an individual cow, based on the individual cow composite SCC from 3 consecutive monthly test milkings (Funke, 1989; Brolund, 1990), 
Table 1. Herd size, average annual herd-level milk production, and udder health data [median and 50\% central range (CR)] of selected and reference herds, and the $95 \%$ confidence limits (CI) for their difference ${ }^{1}$

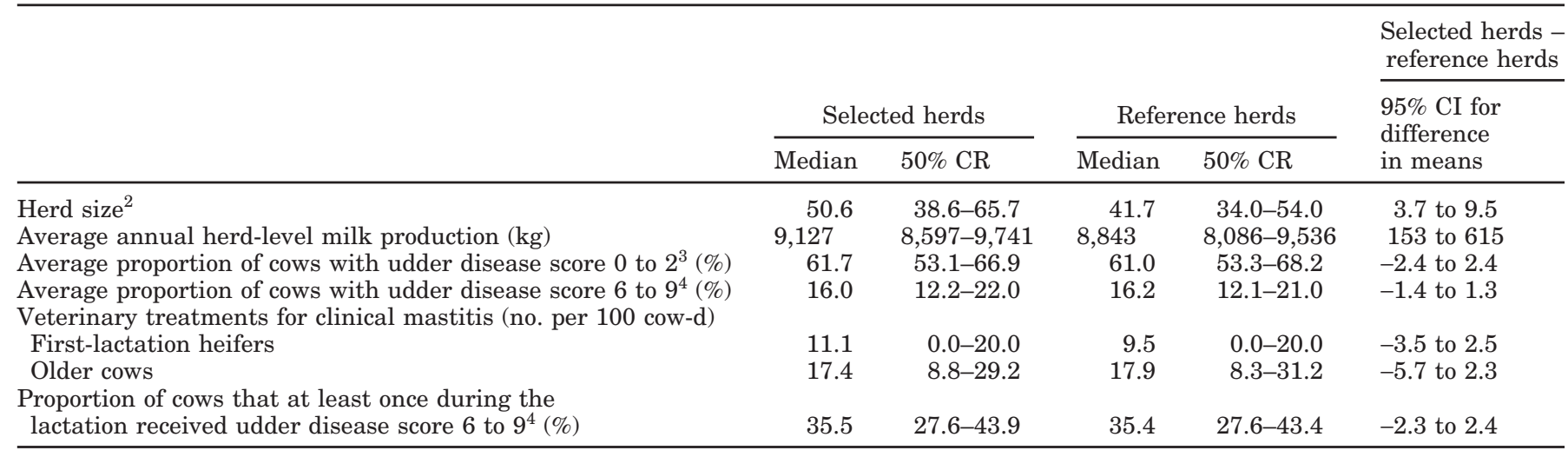

${ }^{1}$ Selected herds $=107$ selected dairy herds with 28 to 94 cows in southwest Sweden; reference herds = the sampling frame from which the experimental herds were selected and consisting of all dairy herds with 28 to 94 cows included in the Swedish official milk- and healthrecording program $(n=5,132)$ from September 2000 to August 2001.

${ }^{2}$ Average number of lactating cows.

${ }^{3}$ Animals with udder disease score (UDS) of 0 to 2 have a probability of 0 to $29 \%$ that 1 or more udder quarters are infected. The score corresponds approximately to having had a SCC of $<131,000$ cells $/ \mathrm{mL}$ on 3 consecutive test milkings.

${ }^{4}$ Animals with a UDS of 6 to 9 have a probability of 69 to $99 \%$ that 1 or more udder quarters are infected. The score corresponds approximately to having had a SCC of $>300,000$ cells $/ \mathrm{mL}$ on 3 consecutive test milkings.

and expresses the probability that a cow has an infection in one or more udder quarters at a given test milking. Cows with UDS 0 to 2 have 0 to $29 \%$ probability of having one or more udder quarters infected. Udder disease score 0 to 2 corresponds approximately to having had a geometric mean composite SCC of $<131,000$ cells/mL on 3 consecutive test milkings. Cows with a UDS of 6 to 9 have a probability of 69 to $99 \%$ of having one or more udder quarters infected; this score corresponds approximately to a composite SCC of $>300,000$ cells/mL on 3 consecutive test milkings.

Information on herd size, average annual herd-level milk production, herd distribution of UDS, and herd incidence of VTCM for the milk recording year (September to August) when most heifers in the study calved (2000-2001) was retrieved for the study herds and also for the sampling frame (reference herds), consisting of all herds in Sweden enrolled in the official milk- and health-recording program and that had 28 to 94 cows.

\section{Data Edits and Statistical Analyses}

The material was analyzed looking at 2 binary outcomes that are both measurements of udder health: mastitis, categorized as presence or absence of VTCM (including cases of trampled teats associated with mastitis) between $7 \mathrm{~d}$ prepartum and $30 \mathrm{~d}$ postpartum, and cow composite SCC at first test milking, categorized as $<200,000$ or $\geq 200,000$ cells $/ \mathrm{mL}$ (Dohoo and Leslie, 1991). Data on SCC from 37 animals were missing because they were culled before first test milking. Associations between each of the 2 binary outcome variables and the health of the calves and their housing, feeding, and management before calving were investigated using a 2-level (animal; herd) variance-components logistic model.

The univariate relationships between potential predictor variables and their particular outcome variable(s) were initially examined variable by variable with herd forced into the model as a random effect, as applied by the SAS macro GLIMMIX (Littell et al., 1996). Unless highly correlated $(r>0.60)$ with other predictors or subject to a considerable number $(>20 \%)$ of missing values, all variables exhibiting a fair degree of association with an outcome variable $\left(P_{\mathrm{F}}<0.20 ; 2\right.$ sided) were offered to an initial multivariate model. The distributions of the animal- and herd-level variables considered in the multivariate analyses and exhibiting a significant association $\left(P_{\mathrm{F}}<0.05 ; 2\right.$-sided $)$ with VTCM -7 to $30 \mathrm{~d}$ postpartum and elevated SCC at first test milking after calving, respectively, in the univariate analyses are given in Tables 2 through 5 . Then, the initial multivariate model was reduced using a backward stepwise procedure, with $P_{\text {Wald 2-sided }}<0.05$, as the exclusion and reentering criterion. Variables with a large number of missing values (amount of concentrates fed to preweaned calves, amount of roughage fed at weaning and at 4 mo of pregnancy, and weaning age) were, thereafter, offered to the models using the same criteria. All first-order interactions were tested one at a time and retained if $P_{\text {Wald 2-sided }}<0.05$. Finally, the possible confounding effects of breed, annual average 
Table 2. Continuous animal- and herd-level variables considered in the multivariate analysis of their associations with veterinarian-treated clinical mastitis (VTCM) at d -7 to 30 postpartum in 2,126 first-lactation heifers from 107 herds in southwest Sweden and exhibiting a significant association $(P<0.05)$ in univariable analyses

\begin{tabular}{|c|c|c|c|c|c|}
\hline \multirow[b]{2}{*}{ Variables } & \multicolumn{4}{|c|}{ VTCM, d -7 to 30 postpartum } & \multirow[b]{2}{*}{$P^{1}$} \\
\hline & $\mathrm{n}$ & Mean & $\mathrm{n}$ & Mean & \\
\hline \multicolumn{6}{|l|}{ Animal level } \\
\hline Growth rate from birth to weaning $(\mathrm{g} / \mathrm{d})$ & 1,911 & 569 & 115 & 524 & 0.032 \\
\hline \multicolumn{6}{|l|}{ Herd level } \\
\hline Amount of roughage at weaning $(\mathrm{kg} / \mathrm{d})$ & 1,239 & 0.92 & 84 & 0.78 & 0.038 \\
\hline Proportion of grains in concentrates fed to heifers aged 11 to $16 \mathrm{mo}$ & 1,950 & 0.82 & 118 & 0.75 & 0.022 \\
\hline Proportion of grains in concentrates fed to heifers aged 17 to $23 \mathrm{mo}$ & 1,799 & 0.86 & 101 & 0.79 & 0.015 \\
\hline Proportion of grains in concentrates fed to heifers 4 mo pregnant & 1,881 & 0.84 & 113 & 0.79 & 0.045 \\
\hline
\end{tabular}

${ }^{1}$ Statistical significance of univariate associations from models accounting for herd-level variation.

herd-level milk yield, and herd size were investigated by entering them in the models. The model fit was assessed by visual examination of plots of ranked standardized herd-level residuals and the Hosmer-Lemeshow goodness-of-fit statistics using percentile groups of herds. The normality of the residuals was tested using the Shapiro-Wilk, Kolgomorov-Smirnov, Cramer-von Mises, and Anderson-Darling tests. All analyses, in- cluding calculations of $95 \%$ confidence limits for the difference between the study herds and the sampling frame, were performed using SAS version 8.2 (SAS Institute Inc., Cary, NC).

In the model of VTCM, 2,068 records from 105 herds were used, and in the model of high SCC, 1,963 observations from 102 herds were used. The number of observations used was lower than the total number due to

Table 3. Categorical animal- and herd-level variables considered in the multivariate analysis of their associations with veterinarian-treated clinical mastitis (VTCM) at d -7 to 30 postpartum in 2,126 first-lactation heifers from 107 herds in southwest Sweden and exhibiting a significant association $(P<0.05)$ in univariable analyses

\begin{tabular}{|c|c|c|c|c|}
\hline Variables & Category & $\begin{array}{l}\text { No. of } \\
\text { animals }\end{array}$ & $\begin{array}{l}\text { Animals } \\
\text { with VTCM } \\
\text { at d }-7 \text { to } 30 \\
\text { postpartum, \% }\end{array}$ & $P^{1}$ \\
\hline \multirow[t]{3}{*}{ Housing system 2 mo prepartum ${ }^{2}$} & Litter pen & 490 & 7.3 & \multirow[t]{3}{*}{0.044} \\
\hline & Cubicle system & 250 & 9.2 & \\
\hline & Long stalls & 540 & 3.5 & \\
\hline \multirow[t]{2}{*}{ Reproductive disease or calving difficulty } & Yes & 26 & 84.0 & \multirow[t]{2}{*}{$<0.0001$} \\
\hline & No & 2,100 & 5.0 & \\
\hline \multicolumn{5}{|l|}{ Herd level } \\
\hline \multirow{4}{*}{$\begin{array}{l}\text { Type of concentrates fed to heifers aged } \\
11 \text { to } 16 \text { mo }\end{array}$} & & & & \multirow{4}{*}{0.0008} \\
\hline & Combination processed/unprocessed grains ${ }^{3}$ & 1,937 & 5.0 & \\
\hline & Only processed grains & 64 & 10.9 & \\
\hline & Different within a season & 67 & 22.4 & \\
\hline Type of concentrates fed to heifers 4 mo pregnant & Different grains within a season & 112 & 17.0 & 0.0059 \\
\hline
\end{tabular}

${ }^{1}$ Statistical significance of univariate associations from models accounting for herd-level variation.

${ }^{2}$ Litter pen $=$ group pen bedded with straw and bedding removed at intervals $>3 \mathrm{mo}$; Cubicle system $=$ loose-housing system with concrete (scraped solid surface or slats) alleys and freestalls for lying; Long stalls = housing system for tied cattle equipped with lockable feeding barriers with stalls long enough to allow for rising and lying down behaviors when feeding barriers are closed and cows do not have access to the feeding table; Short stalls = housing system for tied cattle, where cows have unlimited access to the feeding table and space above feeding table is needed for unrestricted rising and lying down behaviors.

${ }^{3}$ Concentrates consists partly of whole or rolled grains. 
Table 4. Continuous variables (herd-level) considered in the multivariate analysis of their associations with cow composite milk SCC at first test milking (mean $21 \mathrm{~d}$ ) after calving in 2,126 first-lactation heifers from 107 herds in southwest Sweden and exhibiting a significant association $(P<0.05)$ in univariable analyses

\begin{tabular}{|c|c|c|c|c|c|}
\hline \multirow[b]{3}{*}{ Variables } & \multicolumn{4}{|c|}{ SCC at first test milking } & \multirow[b]{3}{*}{$P^{1}$} \\
\hline & \multicolumn{2}{|c|}{$<200,000$ cells $/ \mathrm{mL}$} & \multicolumn{2}{|c|}{$\geq 200,000$ cells $/ \mathrm{mL}$} & \\
\hline & $\mathrm{n}$ & Mean & $\mathrm{n}$ & Mean & \\
\hline Average proportion of cows with udder disease score 0 to $2^{2}(\%)$ & 1,707 & 17.7 & 379 & 18.8 & 0.019 \\
\hline Average proportion of cows with udder disease score 6 to $9^{3}(\%)$ & 1,707 & 60.0 & 379 & 58.1 & 0.014 \\
\hline Proportion of cows with at least 1 udder disease score of 6 to $9^{3}(\%)$ & 1,707 & 36.9 & 379 & 39.0 & 0.014 \\
\hline
\end{tabular}

${ }^{1}$ Statistical significance of univariate associations accounting for herd-level variation.

${ }^{2}$ Animals with udder disease score 0 to 2 have a probability of 0 to $29 \%$ that 1 or more udder quarters are infected. The score corresponds approximately to having had an SCC of $<131,000$ cells $/ \mathrm{mL}$ on 3 consecutive test milkings.

${ }^{3}$ Animals with udder disease score 6 to 9 have a probability of 69 to $99 \%$ that 1 or more udder quarters are infected. The score corresponds approximately to having had an SCC of $>300,000$ cells $/ \mathrm{mL}$ on 3 consecutive test milkings.

missing observations for some of the explanatory variables included in the multivariate models.

Incidence rates were calculated per 100 cow-mo at risk; the total number of days between -7 and $305 \mathrm{~d}$ postpartum contributing from each first-lactation heifer was divided by 30 to give the number of cow-mo at risk. Only the first case of VTCM between -7 and $305 \mathrm{~d}$ postpartum was counted in the numerator.

\section{RESULTS}

The 107 study herds were larger, and had higher average annual herd-level milk production compared with the reference herds within the sampling frame (Table 1).
In total, 229 (10.8\%) of the 2,126 animals were treated by a veterinarian for $\mathrm{CM}$ during their first lactation (305 d), corresponding to an incidence rate of 1.13 cases per 100 cow-mo. Twenty-four (10.5\%) of the diseased animals had more than 1 case of mastitis; 21 animals had 2 cases, 3 had 3 cases. Fifty-one percent of the cases (131 cases in 64 herds) were observed within the period $7 \mathrm{~d}$ before to $30 \mathrm{~d}$ after calving (Figure 1). The mean cow composite SCC at first test milking [occurring on average $21 \mathrm{~d}$ postpartum; $50 \%$ central range (CR; excluding $25 \%$ of the values at each end of the distribution): 12 to $28 \mathrm{~d}$ ] was 66,000 ( $50 \%$ CR: 29,000 to 138,000 ) cells $/ \mathrm{mL}$. Altogether, 379 (18.1\%) of the first-lactation heifers had elevated SCC; i.e., $\geq 200,000$ cells $/ \mathrm{mL}$ at first test milking.

Table 5. Categorical animal- and herd-level variables considered in the multivariate analysis of their associations with cow composite milk SCC at first test milking (mean $21 \mathrm{~d}$ ) after calving in 2,126 first-lactation heifers from 107 herds in southwest Sweden

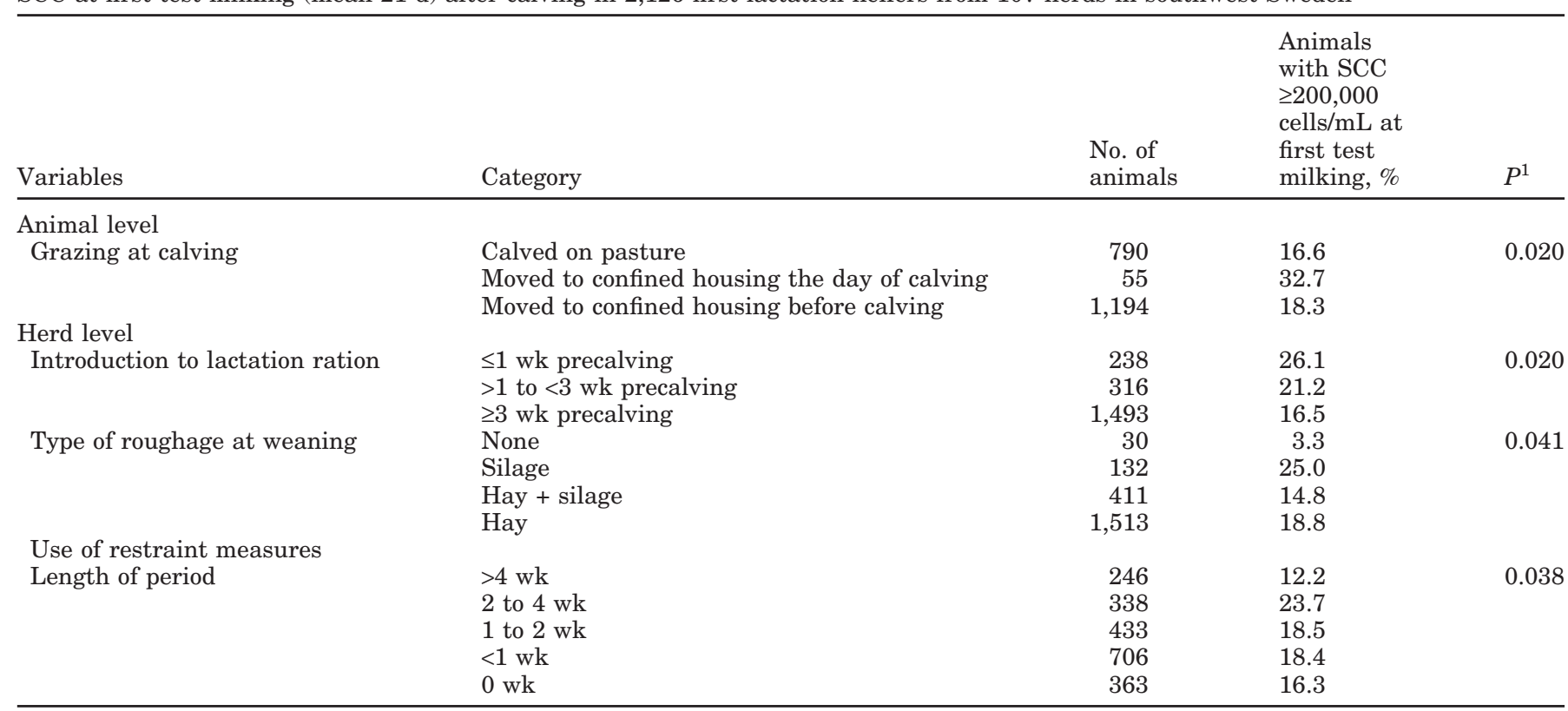

\footnotetext{
${ }^{1}$ Statistical significance of univariate associations accounting for herd-level variation.
} 


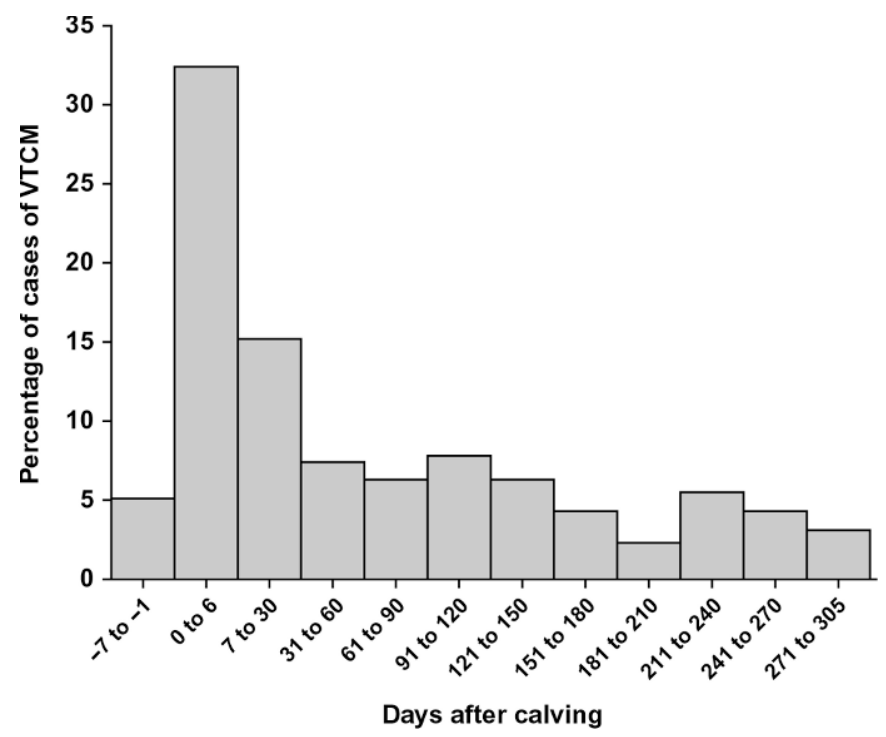

Figure 1. Distribution of cases of veterinarian-treated clinical mastitis (VTCM) from -7 to $305 \mathrm{~d}$ postcalving in 2,164 first-lactation heifers from 107 herds in southwest Sweden ( 256 cases in 229 heifers).

The results from the final multivariate regression model for VTCM -7 to $30 \mathrm{~d}$ postpartum are presented in Table 6 . Veterinarian-treated $\mathrm{CM}$ at -7 to $30 \mathrm{~d}$ postpartum in first-lactation heifers was associated with the overall incidence of mastitis in the herd, and with reproductive disorders (i.e., retained placenta, endometritis, pyometra, dystocia, or twin birth). Each increase of 13.2 percentage units (equal to the $50 \% \mathrm{CR}$ ) in herd mastitis incidence was associated with an odds ratio of 1.7 for the occurrence of VTCM in first-lactation cows. The odds ratio was considerably increased in heifers that had reproductive disorders, compared with heifers without reproductive disorders.

Results from the final multivariate regression model for elevated SCC at first test milking after calving are presented in Table 7. The general udder health in the herd was associated with $\mathrm{SCC} \geq 200,000$ cells $/ \mathrm{mL}$ at first test milking; the odds ratio of having increased SCC in the first-lactation heifers increased with the percentage of cows in the herd that had a UDS of 6 to 9 sometime during the year. Factors associated with SCC $\geq 200,000$ cells $/ \mathrm{mL}$ at first test milking also included amounts of concentrates fed to 11- to 16-moold heifers, grazing in relation to calving, and use of restraint measures at milking. Increasing amounts of concentrates fed to 11- to 16-mo-old heifers were associated with an increased risk of having $\geq 200,000$ cells $/ \mathrm{mL}$, as was moving to confined housing the day of calving compared with moving them before calving or calving on pasture. The use of restraint measures (tying up a leg, stretcher, or other measures, excluding antikicking clamp) was associated with an increased risk of high SCC (Table 7).

In addition, several feed-related variables were associated $(P<0.05)$ with VTCM at -7 to $30 \mathrm{~d}$ postcalving, or SCC $\geq 200,000$ cells $/ \mathrm{mL}$ at first test milking, in the univariate analyses (Tables 2 through 5). Feeding more roughage to calves at weaning was associated with a reduced risk of VTCM at -7 to $30 \mathrm{~d}$ postcalving, as was feeding higher proportions of grains in the concentrates to heifers from 11 to $23 \mathrm{mo}$ of age, or at 4 mo of pregnancy. Using different types of concentrates during the housing period (e.g., grain plus commercial feed during fall/winter and commercial feed only during winter/ spring) was associated with an increased risk of VTCM -7 to $30 \mathrm{~d}$ postcalving. The use of silage as the only roughage to young calves, and to introduce the lactation ration 1 wk or less before calving were associated with an increased risk of SCC $\geq 200,000$ cells/mL at first test milking. We also found an increased growth rate in calves from birth to weaning to be associated with a decreased risk of VTCM -7 to $30 \mathrm{~d}$ postcalving.

Other factors associated with an increased risk of VTCM in the univariate analysis were performing ud-

Table 6. Final multivariate logistic regression model of veterinarian-treated clinical mastitis (VTCM) between $\mathrm{d}-7$ and 30 postpartum in 1,963 first-lactation heifers from 102 herds in southwest Sweden

\begin{tabular}{lllllll}
\hline Variable & Category & $b$ & $\mathrm{SE}(b)$ & OR & $\begin{array}{l}\text { 95\% CI } \\
\text { (OR) }\end{array}$ & $P^{1}$ \\
\hline Intercept & & -3.1 & 1.2 & & & \\
Average annual herd-level milk yield & Continuous & -0.000090 & 0.00013 & & & 0.5 \\
Incidence of VTCM in the herd $^{\text {Reproductive disorders }}{ }^{4}$ & Continuous & 0.041 & 0.0070 & $1.7^{3}$ & 1.4 to 2.1 & $<0.001$ \\
& No & & & 1.0 & & $<0.0001$ \\
& Yes & 4.4 & 0.53 & 81.7 & 28.7 to 232.4 & \\
\hline
\end{tabular}

\footnotetext{
${ }^{1}$ Statistical significance for the overall effect of each variable.

${ }^{2}$ Included in the model as a confounder.

${ }^{3}$ Odds ratio $(\mathrm{OR})$ is calculated for an increase corresponding to the $50 \%$ central range (13.2 percentage units).

${ }^{4}$ Retained placenta, endometritis, pyometra, dystocia, or twin birth.
} 
Table 7. Final multivariate logistic regression model of high cow composite SCC ( $\geq 200,000$ cells $/ \mathrm{mL})$ at first test milking after calving in 2,068 first-lactation heifers from 105 herds in southwest Sweden

\begin{tabular}{|c|c|c|c|c|c|c|}
\hline Variable & Levels & $b$ & $\mathrm{SE}(b)$ & OR & $\begin{array}{l}95 \% \text { CI } \\
\text { (OR) }\end{array}$ & $P^{1}$ \\
\hline Intercept & & -2.9 & 0.38 & & & \multirow{6}{*}{$\begin{array}{l}0.014 \\
0.027\end{array}$} \\
\hline \multirow{5}{*}{$\begin{array}{l}\text { Amount of concentrates to heifers aged } \\
11 \text { to } 16 \mathrm{mo}(\mathrm{kg} / \mathrm{d}) \\
\text { Grazing at calving }\end{array}$} & & & & & & \\
\hline & Continuous & 0.19 & 0.074 & $1.2^{2}$ & 1.0 to 1.3 & \\
\hline & Moved to confined housing before calving ${ }^{3}$ & & & 1.0 & & \\
\hline & Moved to confined housing the day of calving & 0.79 & 0.32 & 2.2 & 1.2 to 4.1 & \\
\hline & Calved at pasture ${ }^{4}$ & -0.089 & 0.13 & 0.9 & 0.7 to 1.2 & \\
\hline \multirow{8}{*}{$\begin{array}{l}\text { Proportion of cows in the herd that } \\
\text { received udder disease score } 6 \text { to } 9^{5} \text { at } \\
\text { least once during the lactation }(\%) \\
\text { Restraint measures }\end{array}$} & & & & & & \multirow{8}{*}{$\begin{array}{l}0.0017 \\
0.0099\end{array}$} \\
\hline & Continuous & 0.30 & 0.09 & $1.3^{2}$ & 1.1 to 1.6 & \\
\hline & None & & & 1.0 & & \\
\hline & Anti-kicking clamp & 0.30 & 0.21 & 1.3 & $0.9-2.1$ & \\
\hline & Leg tied up & 0.88 & 0.42 & 2.4 & $1.1-5.5$ & \\
\hline & Stretcher & 0.62 & 0.30 & 1.8 & $1.0-3.3$ & \\
\hline & Other & 1.1 & 0.31 & 2.9 & $1.6-5.4$ & \\
\hline & Combinations & 0.26 & 0.22 & 1.3 & $0.8-2.0$ & \\
\hline
\end{tabular}

\footnotetext{
${ }^{1}$ Statistical significance for the overall effect of each variable.

${ }^{2}$ Odds ratio (OR) is calculated for an increase corresponding to the $50 \%$ central range $(0.9 \mathrm{~kg}$ and 16.7 percentage units).

${ }^{3}$ Animals were moved to confined housing 1 to 572 (median 85) d before calving.

${ }^{4}$ Animals were turned out to pasture 3 to 569 (median 119) d before calving.

${ }^{5}$ Animals with udder disease score 6 to 9 have a probability of 69 to $99 \%$ that 1 or more udder quarters are infected. The score corresponds approximately to having had a SCC of $>300,000$ cells $/ \mathrm{mL}$ on 3 consecutive test milkings.
}

der examinations less frequently before calving $(\leq 50 \%$ of animals) in contrast to more frequent examinations $(>50 \%$ of animals) and an increased incidence of diseases other than mastitis or reproductive disorders. Significant univariate associations were also found between VTCM at -7 to $30 \mathrm{~d}$ postcalving and housing system 2 mo prepartum, and between elevated SCC at first test milking and length of period that restraint measures were used (Tables 2 through 5 ).

\section{DISCUSSION}

The incidence risk of VTCM during the complete first lactation (305 d) was $10.8 \%$ with an incidence rate of 1.13 cases per 100 cow-mo and half of the cases occurred between $7 \mathrm{~d}$ before and $30 \mathrm{~d}$ after first calving. In Sweden, most cases of CM, especially those in first-lactation heifers, are treated by a veterinarian. Thus, VTCM includes the majority of cases of CM. The incidence risk is within the range previously reported for first-lactation heifers from the Swedish and Finnish official milk- and health-recording programs, but lower than the corresponding figures from Norway and Denmark (Valde et al., 2004). From the Netherlands, Barkema et al. (1998) reported the incidence rate of $\mathrm{CM}$ in primiparous cows in 274 herds to be 4.38 quarter cases per 10,000 cow$\mathrm{d}$ at risk. They also found a high percentage of cases to occur early in lactation, as did Myllys and Rautala (1995), who suggested this concentration of cases to be due to the impaired immune function in the peripartur- ient period as reviewed, for example, by Persson Waller (2000).

The individual incidence risk of elevated SCC at first test milking in the present study was lower than the corresponding figure reported by Bareille et al. (2000) in primiparous cows from 7 to $45 \mathrm{~d}$ in milk in 228 French dairy herds. Our mean SCC at first test milking was similar to their median SCC, but lower than the mean SCC reported by De Vliegher et al. (2001, 2004), although those researchers investigated the SCC in firstlactation heifers between $\mathrm{d} 5$ and 14 postpartum; that is, earlier postcalving than most results from the present study.

In the multivariate analysis, none of the predictors related to the housing, management, or health of the calf and the heifer precalving and around calving was significantly associated with the risk of VTCM from $7 \mathrm{~d}$ before to $30 \mathrm{~d}$ after first calving. However, in agreement with Waage et al. (1998) and Myllys and Rautala (1995), we found an increased risk of VTCM -7 to $30 \mathrm{~d}$ postcalving in herds with high incidence of mastitis. This may have been due to an increased risk of transmission of udder pathogens in such herds. Risks of intramammary infections in heifers increase when they are housed together with older cows (Barkema et al., 1999; Bareille et al., 2004). Risk of VTCM is also affected by the farmer's attitude toward treating mastitis (Vaarst et al., 2002).

Cows with reproductive disorders also had an increased risk for VTCM -7 to $30 \mathrm{~d}$ postcalving. An associ- 
ation between mastitis in early lactation and dystocia was also reported by Bendixen et al. (1988) and Bareille et al. (2004), whereas Emanuelson et al. (1993) did not find such an association. Several researchers have reported an association between retained placenta and CM (e.g., Bendixen et al., 1988; Schukken et al., 1988; Emanuelson et al., 1993). There are several reasons for reproductive disorders to occur and it is possible that the association between reproductive disorders and mastitis that we found could be due to a common factor affecting both disease complexes.

In contrast to VTCM, we found elevated SCC at first test milking to be associated with several management variables; that is, increasing amounts of concentrates fed to 11- to 16-mo-old heifers, moving to confined housing the day of calving, and the use of restraint measures when introducing the animals to milking. Elevated SCC at first test milking in primiparous cows was also associated with poor udder health in the herd, measured as the percentage of cows that had a UDS of 6 to 9 (chronically elevated SCC) at least once during the year. Some evidence for associations between udder health and generous concentrate feeding has been proposed in the literature (Johnson and Otterby, 1981; Schukken et al., 1991; Waage et al., 1998). This is in accordance with our findings of an increased risk for elevated SCC at first test milking at increasing amounts of concentrates fed to 11- to 16-mo-old heifers. The studies by Pedersen (1975) and Bareille et al. (2000) indicate that excessive protein (or other factors resulting in high blood urea concentrations) may be one possible explanation for these results. On the other hand, Bareille et al. (2004) found low concentrate feeding and low milk urea levels in early lactation, possibly due to underfeeding, to be a risk factor for clinical mastitis in dairy heifers around calving, illustrating the complex nature of the potential association between urea or protein feeding and udder health. In our univariate analysis, we also found an increased risk of VTCM at -7 to $30 \mathrm{~d}$ postpartum when the concentrates contained a lower proportion of grains, and when different types of concentrates were used during the housing period. Together, these results indicate that the feeding of heifers, especially feeding of concentrates is important for their subsequent udder health, but further studies are needed to elucidate the causative relationships.

Handling and novelty may be strong stressors (Grandin, 1997). If those stressors are introduced around calving, when a periparturient immune suppression is already present in most dairy cows, they may further increase the susceptibility to infectious diseases like mastitis (reviewed by Persson Waller, 2000). In addition, introduction of machine milking after calving may be so stressful to some heifers that milk ejection is inhibited (Van Reenen et al., 2002). Kicking and stepping at milking, often due to unfamiliar environment or a painful udder, is common in such heifers, which may result in the use of restraint measures at milking. In the present study, the use of such measures was associated with an increased SCC after calving. Inhibition of milk ejection results in incomplete milking, which may increase the risk for milk leakage and increased SCC (Persson Waller et al., 2003). In most herds, restraint measures were only used on a small proportion of the heifers indicating that those heifers showed adverse responses at milking, which may have led to inhibition of milk ejection. To our knowledge, this is the first report of an association between restraint measures and mastitis. However, because little is known about the effects of such measures on the physiology of the animals, the results must be interpreted with care. The result that poor udder health in the herd was associated with an increased risk of elevated SCC in the primiparous cows is in agreement with findings by Bareille et al. (2000) and De Vliegher et al. (2004), and may be explained by an increased risk of transmission of udder pathogens in the herd.

Little evidence of the impact of calf health on subsequent udder health was gained from the present study. However, because it has been shown that healthier calves gain more weight (Virtala et al., 1996; Donovan et al., 1998; Lundborg et al., 2003) the results of the univariate analysis that an increased growth rate in calves from birth to weaning was associated with a decreased risk of VTCM - 7 to $30 \mathrm{~d}$ postcalving may be taken as an indication that keeping calves healthy is beneficial in terms of the udder health of the animals postcalving.

\section{CONCLUSIONS}

Our results are consistent with previous studies in that most cases of VTCM in primiparous cows occur early in lactation. Little evidence of the impact of calf health on subsequent udder health was gained from the present study. Instead, the results substantiate earlier findings that the general udder health in the herd and presence of reproductive disorders are important factors for the incidence of VTCM and high SCC in primiparous cows during early lactation. Moreover, avoiding the factors that contribute to increased stress around the time of parturition may be beneficial. Our findings support previous indications that feeding precalving (especially that of concentrates) may affect early lactation udder health in primiparous cows, and indicate that this is an important topic for further research. 


\section{ACKNOWLEDGMENTS}

The study was financially supported by the Swedish Farmers' Foundation for Agricultural Research, the Swedish Dairy Association, and the Swedish University of Agricultural Sciences (SLU). The authors thank the participating farmers for their interest and support. Lotta Andersson, Karin Lundborg, and Jonica Östlund (SLU) and staff from Skara Regional Dairy Association are acknowledged for their help in data collection. We are grateful to Gunilla Jacobsson (SLU), and to Ulf Rundström, Kjell Johansson, and Ann Lindberg (Swedish Dairy Association) for their help in data processing, and to Sven-Ove Olsson (Swedish Dairy Association) for help in initiating the study.

\section{REFERENCES}

Andersson, L. 1988. Swedish dairy herd health programmes based on routine recording of milk production, fertility data, somatic cell counts and clinical diseases. Pages 190-194 in Proc. 6th Int. Congr. Anim. Hyg., Skara, Sweden. Västergötlands Tryckeri AB, Skara, Sweden.

Bareille, N. H., B. Djabri, F. Beaudeau, and H. Seegers. 2004. Risk factors for clinical mastitis and for new intramammary infection in dairy heifers around calving. Le Médec. Véterin. Quebec 34:159. (Abstr.)

Bareille, N., H. Seegers, M. B. Kiebre-Toe, F. Beaudeau, and C. Fourichon. 2000. Risk factors for elevated milk somatic cell count during early lactation in dairy heifers. Pages 509-514 in Proc. 10th Int. Congr. Anim. Hyg., Maastricht, The Netherlands. ADDIX, Wijk bij Duurstede, The Netherlands.

Barkema, H. W., Y. H. Schukken, T. J. G. M. Lam, M. L. Beiboer, G. Benedictus, and A. Brand. 1999. Management practices associated with the incidence rate of clinical mastitis. J. Dairy Sci. 82:1643-1654.

Barkema, H. W., Y. H. Schukken, T. J. G. M. Lam, M. L. Beiboer, H. Wilmink, G. Benedictus, and A. Brand. 1998. Incidence of clinical mastitis in dairy herds grouped in three categories by bulk somatic cell counts. J. Dairy Sci. 81:411-419.

Bendixen, P. H., B. Vilson, I. Ekesbo, and D. B. Astrand. 1988. Disease frequencies in dairy cows in Sweden. V. Mastitis. Prev. Vet. Med. $5: 263-274$.

Brolund, L. 1990. Technical utilization of cell count in the milkrecording service (Cellhaltens tekniska utnyttjande i kokontrollen). Pages 40-41 in Djurhälsovård 88/89. Meddelande nr 161. Swedish Association for Livestock Breeding and Production, Eskilstuna, Sweden. [in Swedish]

DeGraves, F. J., and J. Fetrow. 1993. Economics of mastitis and mastitis control. Vet. Clin. North Am. Food Anim. Pract. 9:421-434.

De Vliegher, S., H. Laevens, H. W. Barkema, I. R. Dohoo, H. Stryhn, G. Opsomer, and A. de Kruif. 2004. Management practices and heifer characteristics associated with early lactation somatic cell count of Belgian dairy heifers. J. Dairy Sci. 87:937-947.

De Vliegher, S., H. Laevens, G. Opsomer, E. De Mûeleanaere, and A. de Kruif. 2001. Somatic cell counts in dairy heifers during early lactation. Vlaams Diergeneeskd. Tijdschr. 70:212-215.

Dohoo, I. R., and K. E. Leslie. 1991. Evaluation of changes in somatic cell counts as indicators of new intramammary infections. Prev. Vet. Med. 10:225-237.

Donovan, G. A., I. R. Dohoo, D. M. Montgomery, and F. L. Bennet. 1998. Calf and disease factors affecting growth in female Holstein calves in Florida. Prev. Vet. Med. 33:1-10.

Edinger, D., B. A. Tenhagen, W. Heuwieser, P. Kalbe, G. Klunder, and B. Baumgartner. 1999. Effect of early puerperal mastitis in primiparous cows on production, somatic cell count and culling. Deutsch. Tieararztl. Wochenschr. 106:470-474.

Emanuelson, U., and C. Hallén Sandgren. 1997. A comparison of high yielding Swedish dairy herds with low somatic cell counts and with high or low incidence of clinical mastitis. Epidémiol. Santé Anim. 31-32:05.14.01-05.14.3.

Emanuelson, U., P. A. Oltenacu, and Y. T. Gröhn. 1993. Nonlinear mixed model analyses of five production disorders of dairy cattle. J. Dairy Sci. 76:2765-2772.

Funke, H. 1989. Udder inflammation - cell count. Interpretation and practical use of cell counts in cow samples. (Juverinflammationer - cellhalt. Tolkning och praktisk användning av cellhalter i koprov). Meddelande Nr 156. Association for Livestock Breeding and Production, Eskilstuna, Sweden. [in Swedish]

Grandin, T. 1997. Assessment of stress during handling and transport. J. Anim. Sci. 75:249-257.

Hessle, A., E. Nadeau, and C. Svensson. 2004. Feeding dairy calves and replacement heifers in south-western Sweden - a survey. Acta Agric. Scand. 54:94-102.

Hortet, P., F. Beaudeadu, H. Seegers, and C. Fourichon. 1999. Reduction in milk yield associated with somatic cell counts up to 600 000 cells $/ \mathrm{ml}$ in French Holstein cows without clinical mastitis. Livest. Prod. Sci. 61:33-42.

Johnson, D. G., and D. E. Otterby. 1981. Influence of dry period diet on early postpartum health, feed intake, milk production, and reproductive efficiency of Holstein cows. J. Dairy Sci. 64:290-295.

Littell, R. C., G. A. Milliken, W. W. Stroup, and R. D. Wolfinger. 1996. SAS System for Mixed Models. SAS Inst., Inc., Cary, NC.

Lundborg, G. K., P. A. Oltenacu, D. O. Maizon, E. C. Svensson, and P. G. A. Liberg. 2003. Dam-related effects on heart girth at birth, morbidity and growth rate from birth to 90 days of age in Swedish dairy calves. Prev. Vet. Med. 60:175-190.

Myllys, V., and H. Rautala. 1995. Characterization of clinical mastitis in primiparous heifers. J. Dairy Sci. 78:538-545.

Oliver, S. P., and B. A. Mitchell. 1983. Intramammary infections in primigravid heifers near parturition. J. Dairy Sci. 66:1180-1183.

Olsson, S.-O., P. Baekbo, S. Ö. Hansson, H. Rautala, and O. R. Østerås. 2001. Disease recording systems and herd health schemes for production diseases. Acta Vet. Scand. Suppl. 94:51-60.

Østerås, O. R., B. Larssen, and E. Simensen. 1997. Environmental risk factors associated with mastitis in heifers. Pages 40-41 in Proc. 9th Int. Congr. Anim Hyg., Helsinki, Finland. Tummavuoren Kirjapaino Oy, Helsinki, Finland.

Pankey, J. W., P. A. Drechsler, and E. E. Wildman. 1991. Mastitis prevalence in primigravid heifers at parturition. J. Dairy Sci. 74:1550-1552.

Pedersen, P. S. 1975. Prevention of mastitis in cows. Page 249 in Seminar on Mastitis Control. F. H. Dodd, T. F. Griffen, and R. G. Kingwill, ed. Int. Dairy Fed., Brussels, Belgium.

Persson Waller, K. 2000. Mammary gland immunology around parturition. Influence of stress, nutrition and genetics. Adv. Exp. Med. Biol. 480:231-245.

Persson Waller, K., T. Westermark, T. Ekman, and K. SvennerstenSjaunja. 2003. Milk leakage - An increased risk in automatic milking systems. J. Dairy Sci. 86:3488-3497.

Rajala-Schultz, P. J., Y. T. Grøhn, C. E. McCulloch, and C. L. Guard. 1999. Effects of clinical mastitis on milk yield in dairy cows. J. Dairy Sci. 82:1213-1220.

Schukken, Y. H., H. N. Erb, and R. D. Smith. 1988. The relationship between mastitis and retained placenta in a commercial population of Holstein dairy cows. Prev. Vet. Med. 5:181-190.

Schukken, Y. H., F. J. Grommers, D. van der Geer, H. N. Erb, and A. Brand. 1991. Risk factors for clinical mastitis in herds with a low bulk milk somatic cell count. 2. Risk factors for Escherichia coli and Staphylococcus aureus. J. Dairy Sci. 74:826-832.

Seegers, H., C. Fourichon, and F. Beaudeau. 2003. Production effects related to mastitis and mastitis economics in dairy cattle herds. Vet. Res. 34:475-491.

Swedish Dairy Association. 2005. Cattle statistics. Eskilstuna Offset $\mathrm{AB}$, Eskilstuna, Sweden. 
Trinidad, P., S. C. Nickerson, and T. K. Alley. 1990. Prevalence of intramammary infection and teat canal colonization in unbred and primigravid dairy heifers. J. Dairy Sci. 73:107-114.

Vaarst, M., B. Paarup-Laursen, H. Houe, C. Fossing, and H. J. Andersen. 2002. Farmers' choice of medical treatment of mastitis in Danish dairy herds based on qualitative research interviews. J. Dairy Sci. 85:992-1001.

Valde, J. P., L. G. Lawson, A. Lindberg, J. F. Agger, H. Saloniemi, and O. Østerås. 2004. Cumulative risk of bovine mastitis treatments in Denmark, Finland, Norway and Sweden. Acta Vet. Scand. 45:201-210.

Van Reenen, C. G., J. T. N. Van der Werf, R. M. Bruckmaier, H. Hopster, B. Engel, J. P. T. M. Noordhuizen, and H. J. Blokhuis.
2002. Individual differences in behavioral and physiological responsiveness of primiparous dairy cows to machine milking. J. Dairy Sci. 85:2551-2561.

Virtala, A.-M. K., G. D. Mechor, Y. T. Gröhn, and H. N. Erb. 1996. The effect of calfhood diseases on growth of female dairy calves during the first $3 \mathrm{mo}$ of life in New York State. J. Dairy Sci. 79:1040-1049.

Waage, S., H. R. Skei, J. Rise, T. Rogdo, S. Sviland, and S. A. Ødegaard. 2000. Outcome of clinical mastitis in dairy heifers assessed by reexamination of cases one month after treatment. J. Dairy Sci. 83:70-76.

Waage, S., S. Sviland, and S. A. Ødegaard. 1998. Identification of risk factors for clinical mastitis in dairy heifers. J. Dairy Sci. $81: 1275-1284$. 